Article

\title{
Social Entrepreneurship as a Form of Cross-Border Cooperation: Complementarity in EU Border Regions
}

\author{
Herman T. Wevers, Cosmina L. Voinea *(D) and Frank de Langen \\ Faculty of Management, Open University of the Netherlands, 6419 AT Heerlen, The Netherlands; \\ hans.wevers@ou.nl (H.T.W.); Frank.deLangen@ou.nl (F.d.L.) \\ * Correspondence: cosmina.voinea@ou.nl
}

Received: 7 September 2020; Accepted: 28 September 2020; Published: 14 October 2020

check for updates

\begin{abstract}
EU border regions continue to face economic and social disadvantages compared to other regions in the same country. Since 1990, the European Commission has been implementing extensive territorial cooperation programs to support EU border regions in solving regional problems and building social cohesion. This study offers a contribution for decreasing the economic and social disadvantages of EU border regions by investigating the complementarity between institutional EU cross-border cooperation and social entrepreneurship. We argue that both concepts build upon similar drivers and characteristics with the aim of creating impact and bringing about change. We test and improve our initially literature-based framework to provide a better insight into how institutional and entrepreneurial processes could benefit from each other. We conduct interviews with experts operating at different governance levels and in various EU countries and border regions. The complementarity between both concepts is confirmed considering a differentiation between governance levels and fields of expertise. The results show that complementarity between the concepts mainly exists in terms of taking advantage of opportunities for a certain effect. The commercial activities of social enterprises are seen as effective, but it is necessary for social enterprises to establish sustainable EU cross-border cooperation and to improve regional social and economic development.
\end{abstract}

Keywords: cross-border cooperation; social entrepreneurship; local embeddedness; social capital; institutional EU

\section{Introduction}

Institutional EU cross-border cooperation and social entrepreneurship have a common ground from which to start their activities. Although there are fundamental differences between the institutional and entrepreneurial approaches, both concepts turn social and economic problems into opportunities with the objective of creating impact and bringing about change. Therefore, we argue that an untapped potential may exist in the complementarity between both concepts. The European Commission (EC) stated in 2015 that "Recent years have seen a burgeoning interest in social enterprise across Europe, strongly driven by a growing recognition of the role social enterprise can play in tackling societal and environmental challenges and fostering inclusive growth" [1]. We aim to reframe this statement of the European Commission (EC) in the context of institutional EU cross-border cooperation by investigating the role of social entrepreneurship as a micro-economic approach involving communities and businesses in the economic and social development of border regions and contributing to social cohesion.

Thus, the EC acknowledges the role that social enterprises could play in tackling societal and environmental problems and fostering more inclusive growth [1]. In the context of EU cross-border cooperation, we observe similarities between the policy objectives of EU territorial programs such as Interreg (e.g., inclusive growth, a lower carbon economy, environment, resource efficiency) and the field of play of social enterprises (e.g., inclusiveness, circularity, employment, health, mobility). Knowing 
that local citizens and communities are involved in the business processes of social enterprises [2-4] and that national traditions and sensitivities are taken into account [3], we argue that a potential positive contribution of social entrepreneurship to institutional EU cross-border cooperation may exist. This leads us to our central research question:

"What complementarity is there between social entrepreneurship and institutional EU cross-border cooperation?"

In order to build a clear theoretical framework, we apply the following definitions for the concepts of social entrepreneurship and EU cross-border cooperation, respectively. First, we want to make a clear distinction between social entrepreneurship versus commercial entrepreneurship and non-governmental organizations (NGOs). To meet this requirement, we use the definition of social businesses provided by Yunus et al. (2010) [5]: "A social business operates like a regular business and has a similar design, but has a primary purpose to serve society. Furthermore, a social business is self-sustaining and repays its owners' investments" [5]. In the current paper, we use the terms "social entrepreneurship" and "social enterprise" interchangeably and in line with the given definition, thus interpreting them as representing a social business. Moreover, social entrepreneurship includes cooperative arrangements which prevail over competition and shareholder value. For this reason, we exclude purely commercially-driven entrepreneurs from the current research. Pursuing profit maximization may not always benefit cooperative arrangements in the EU border region and therefore may not always be in the interest of regional stakeholders.

Second, we have to establish what can be included beneath the umbrella of EU cross-border cooperation. Since 1990, the EC has applied EU-funded territorial programs to enhance EU cross-border cooperation and strengthen social cohesion. EU territorial programs, such as Interreg, endeavor to improve cooperation between EU Member States with program objectives defined by the EC and regional stakeholders. The Interreg program applies a project-based approach for cooperation and is a key policy instrument to implement the EC's cohesion policy in EU border regions [6]. The Interreg program is mainly implemented by Euregions, which are widely known as tools of cooperation among the regions [7-9]. Euregions are formalized, administrative-territorial structures that are set up to promote cross-border cooperation, mainly through the Interreg program between neighboring local or regional authorities [8]. Indeed, well-established Euregions can be an asset to the daily life of local populations, helping to diffuse a "European way of thinking" [10]. This leads us to the definition of EU cross-border cooperation formulated by Sousa (2013) [10]: "Any type of concerted action between public and/or private institutions of the border regions of two (or more) states, driven by geographical, economic, cultural/identity, political/leadership factors, with the objective of reinforcing the (good) neighborhood relations, solving common problems or managing jointly resources between communities through any co-operation mechanisms available" [10]. This definition provides us with sufficient room for social enterprises in the role of private institutions. However, we have to consider the possible, more critical vision of the functioning of Euregions as politically-led projects which are not obviously supported by local citizens and/or businesses communities [6-10].

Compared to more central regions in EU Member States, different EU border regions face social and economic disadvantages and reduced investments that accelerate movements to more central regions in country states [1,11,12]. Additionally, EU border regions have to deal with geographic, historical, cultural, and language barriers, limiting their opportunities for cooperation with their neighboring counterparts [12-14]. Mutual feelings of distrust and animosity against neighboring countries still exist in several EU border regions [6,15-17]. Because about one-third of European citizens (150 million people) live in EU border regions, the EC, national, and regional authorities cannot neglect the specific problems of EU border regions.

Reflecting on the current cross-border cooperation Interreg programs, which have run from 2014-2020, and looking forward to the new program period of 2021-2027, the EC recognizes the need for measures that go beyond EU funding to bring Europe closer to its citizens [18]. The publication presenting these reflections provides an insight with a series of concrete actions which potentially 
contribute to both socio-economic development and integration of border regions [12]. These actions may be seen as a next step towards a Europe closer to businesses and citizens. Moreover, in the EC's regional development and cohesion policy strategy for 2021-2027, the EC defines five objectives to drive future EU investments in regional development: (1) A smarter Europe, (2) a greener carbon free Europe, (3) a more connected Europe, (4) a social Europe, and (5) a Europe closer to the citizens [18]. Following the social entrepreneurial processes of Belz and Binder (2015) [19], social entrepreneurs search for ecological and social problems which can be converted into business opportunities. Driven by their social missions, social entrepreneurs deploy social business models which connect the mission to the value proposition of the enterprise [20]. Thereby, the social entrepreneur searches for engagement with local communities and combines society with an action based entrepreneurial approach [21].

In the last decades, literature investigating EU cross-border cooperation had a mostly institutional focus and research on cross-border entrepreneurship (Jørgenson et al. (2011) [22], Leick (2011) [23], and Smallbone and Welter (2012) [24] was clearly in the minority. More recently, however, we see a shift towards research conducted on different topics in the field of EU cross-border cooperation and entrepreneurial involvement (Böhm and Opiola (2019) [14], Chobal and Lalakulych (2019) [25], Jelinčić et al. (2019) [26], Kurowska-Pysz (2016) [27], and Stverkova et al. (2018) [28] These studies offer valuable insights in cross-border cooperation processes with a focus on specific geographic regions. However, none of these studies involves social entrepreneurship. Hence, our main aim is to contribute to this gap in the knowledge on cross-border entrepreneurship through investigating the existence of complementarity between social entrepreneurship and institutional EU cross-border cooperation.

Theoretical implications of our research follow up on research directions indicated by Stverkova et al. (2018) [28], aiming at a better understanding of cross-border entrepreneurship in different Euregions and industries. An interesting direction for future research connects with the work of Kurowska-Pysz (2016) [27] concerning the extension of clusters for cross-border cooperation. Furthermore, our study aims to contribute to the understanding on how social entrepreneurship and institutional EU cross-border cooperation are complementary concepts, which endeavor similar objectives but apply different approaches. A main insight we gain from our empirical results is how complementarity between both concepts on local governance level leads to genuine bottom-up and opportunity-driven sustainable cross-border cooperation. Through a different research design compared to existing cross-border entrepreneurship studies, we gain insights in the perspectives of institutional EU cross-border cooperation experts on the role of social entrepreneurship in cross-border regions. And the other way around, the perspectives of social enterprise experts on reaching out across the border. Finally, we aim to contribute to the theory of social entrepreneurial opportunity-driven processes as mentioned by Belz and Binder (2015) [19].

Our research has practical implications for policy makers involved in both social entrepreneurship and institutional EU cross-border cooperation. Indeed, the EC promotes social entrepreneurship providing valuable reports on social enterprise ecosystems per country [1]. But we reveal how social enterprise experts on the EU and national level are still reluctant to cooperate with EU institutions. Therefore, EU institutional experts could make an attempt at conciliation to social enterprise interest organizations through improving social businesses support and communication of good practices. We welcome the continuation of people-to-people projects in border regions supported by the current cross-border cooperation programs. Further analyzing the results of these type of bottom-up small-scale projects could offer future opportunities for social entrepreneurship. For instance, in the form of community ownership models. Another aspect that needs more support from policy maker's concerns different type of barriers faced by social entrepreneurs, such as high transaction costs, a lack of trust, and language problems. But also, legal issues, rules, and regulations limit the participation of entrepreneurs in cross-border cooperation projects. Strengthening the business development and support function of Euregions could contribute to the mitigation of these barriers. 


\section{Literature Review}

\subsection{Drivers}

According to the strategy as described in the Interreg Cooperation Document (2015), the EC strives for a smart, sustainable, and inclusive growth and for achieving economic, social, and territorial cohesion. In line with this strategy, Portolés (2015) [11] argued that EU cross-border cooperation is driven by finding solutions to existing social and economic problems and broadening economic opportunities for private actors and citizens of border regions. Kurowska-Pysz and Szczepańska-Woszczyna (2017) [13] found that next to funding opportunities, partnerships in the Polish-Lithuanian border regions are established to jointly solve system problems and system support at national, regional, and local level. Through policy instruments like Interreg, the EC stimulates border regions to tackle shared regional problems through bi- or multi-lateral cooperation [11,29]. Interreg as a policy instrument, however, is strongly embedded in a public institutional environment [6]. As a consequence, the dominant type of institutional EU cross-border cooperation occurs mainly between local and regional governments, NGOs, and universities but with much less involvement of enterprises [6,27].

Social enterprises, in contrast to institutionalized EU cooperation processes, find their origin on a micro-economic or even grass roots level. Thereby, social business models primarily link social missions to social objectives [20]. "When social value creation is purposeful and explicitly anchored in a firm's business model, the literature usually speaks of a social enterprise" [4,20]. Because social enterprises engage in a broad spectrum of activities while pursuing their mission, the social objectives are also defined broadly, e.g., the creation of social wealth [30], social value [31], or the implementation of social change [32,33]. Belz and Binder (2017) [19] show how social entrepreneurial processes start at recognizing a social, economic, or ecological problem and turn this problem into an opportunity. Social enterprises, thereby, have the capacity to remove barriers hindering social inclusion, support the temporarily weakened groups, and/or mitigate the undesirable effects of economic activity [34].

Regardless of their approach, institutional EU cross-border cooperation and social entrepreneurship are both opportunity-driven activities with delivery models that build upon cooperation. Given the geographic context, Kurowska-Pysz (2016) [27] argues that being established in a border region does not automatically mean an enterprise treats the neighboring market as a natural expansion area. In order to do so, social enterprises need to find bilateral businesses partners and invest in marketing campaigns to enter the cross-border market. Because Euregions implement institutional EU programs such as Interreg, business development support provided by the Euregions could strengthen social enterprises' interest in creating social cohesion. Therefore, we formulate the following assumption:

Assumption 1. Regional problems in EU border regions as defined in policy objectives and specific objectives by institutional EU cross-border cooperation programs create bilateral economic, social, and business opportunities for social entrepreneurship.

\subsection{Characteristics}

Embeddedness refers to the way in which relational, institutional, and cultural contexts shape economic and social life. We define local embeddedness as being embedded in these contexts on the level of local communities and citizens. Local embeddedness is an important asset to develop cross-border cooperation. The interest in local circumstances and a shared set of motives will encourage people to develop and maintain cooperation [35]. But it cannot be taken for granted that institutional EU cross-border cooperation is locally embedded. Institutional EU cross-border cooperation seems to have a stronger embeddedness in regional governmental structures [29], which is also expressed in bilateral partnerships in cross-border cooperation [27]. The lack of involvement of local actors, such as citizens and businesses, in institutional EU cross-border projects is more often questioned by researchers $[6,10,27,36]$. On the other hand, there are examples of well-functioning, but less local embedded Euregions. Koch (2018) [37] reported on how actors involved in cooperation processes 
in the Finnish-Russian border region endorse the effectiveness of top-down organized cross-border cooperation [37]. In this study it was found that the top-down structure works as a trust-building element which allows project managers to better define objectives and seek guidance.

Institutionalized EU cross-border cooperation is a highly cognitive, dynamic, and complex process. After 25 years of Interreg the EC is aware of the critical remarks, which are taken into account in the objectives of the new program period 2021-2027, e.g., a more social Europe and a Europe closer to the citizens. In advance to the new program period, the regional development programs started with calls for micro-projects, e.g., People-to-People projects [38]. By reaching out to local citizens in the border regions, the EU programs become more embedded at a grassroots level and should motivate citizens to engage in cross-border cooperation initiatives.

Examples of cross-border entrepreneurship in the EU border regions demonstrate how entrepreneurial activities are characterized by a strong local embeddedness. Because of its local embeddedness, micro-economic cross-border cooperation benefits from a shared understanding, knowledge of the region, and good neighborhood relations $[24,37,39,40]$. To establish a business across the border, the entrepreneur should not only be aware of local markets, institutions, and cultures but also of what really matters to local people. The same accounts for social entrepreneurship. Local embeddedness is rooted in the social business model as a value proposition which may lead to a competitive advantage. Social enterprises integrate traditional behavior, local sensitivities, and local value creation in their business processes $[2,4,34,41]$. Social enterprises internalize a local focus through different elements of their business models, e.g., the involvement of citizens in their business processes [2,3] or the respect for national traditions and sensitivities [2].

We argue that the local embeddedness of social entrepreneurship could complement and strengthen the local embeddedness of institutionalized EU cross-border cooperation. Because social business models incorporate the involvement of local communities [20], social enterprises may very well contribute to a Europe closer to the citizens. Moreover, the institutional embeddedness of Euregions may improve social entrepreneurial networks and how these networking activities provide access to resources $[4,42]$. Social enterprises use their community or grassroots level embeddedness and relational ties with stakeholders to secure external resources that, in turn, create opportunities for social action [43]. Therefore, we formulate the following assumption:

Assumption 2. The local embeddedness of social entrepreneurship and institutional EU cross-border cooperation mutually reinforce each other, thereby decreasing local/regional daily life problems.

The effectiveness of institutional EU cross-border cooperation activities depends on the existence of social capital between actors at all governance levels involved in cooperation processes [11,37,44]. Social capital is an actual and potential asset for cooperation embedded in relationships among individuals, communities, networks, and societies [30]. More specifically, this means that social capital can be created through collaborating with the local community, strengthening neighborhood relations, improving feelings of trust and safety, and increasing the value of life. One of the key elements of social capital and conditional to effective and productive cooperation is trust [6]. In a publication celebrating of 25 years of Interreg, the EC (2015) [1] states that trust building is a precondition to cooperation between Europeans. And although a lack of trust is not seen as being the most important EU border obstacle [45], trust building is fundamental in EU cross-border cooperation [1,13].

The role of social capital is also endorsed in cross-border entrepreneurship, where bilateral relations rely on elements like trust, reciprocity, interdependency, and neighborliness [23,24,28,40]. However, all these studies have a focus on commercial enterprises, whereas social capital for social enterprises has an extra dimension: the hybrid organization pursues a social mission by making use of market-based strategies [46,47]. Spear and Bidet (2005) [48] mention social capital as a permanent source of resources for social enterprises. Because social capital is an important asset to establish and maintain commercial relations, social enterprises incorporate the creation and usage of social capital both as a means and as an end [20,31,32,48-50]. 
Trust, reciprocity, and interdependency are strongly intertwined and, as such, important elements of social capital. To be effective in their efforts, both institutional EU cross-border cooperation and social entrepreneurship are highly dependent on these elements. Social entrepreneurship may catalyze such social transformation through meeting social needs [30]. We argue that the usage and creation of social capital may contribute to the establishment of bilateral sustainable cooperative engagements. The business models of social enterprises transform input delivered by local communities or neighborhood relations into outputs that fulfil certain needs of the border regions like cohesion and cooperation. As a result, these transformation processes may create a form of cross-border cooperation and complement institutional EU cross-border cooperation. Therefore, we formulate the following assumption:

Assumption 3. The exchange of social capital between institutional EU cross-border cooperation and social entrepreneurship decrease local/regional daily life problems.

Cross-border entrepreneurship contributes to economic development in the border region through economic integration and improvement of societal prosperity [21,23,27,28]. Although long-term bilateral cooperation between business partners strengthens cross-border relations, substantial impact of regional development needs further establishment of new partnerships and development of network opportunities [27]. Because of entrepreneurships' contribution to regional development, issues like mutual cooperation, building relations, and growth of labor productivity are important long-term aspects and entrepreneurship should be supported by local institutional organizations $[14,28]$. Given the context of cross-border cooperation, we argue that the contribution of social entrepreneurship comes from the capacity to build new economic and social cooperation with local communities, businesses, and/or organizations [46]. Thereby, commercial activities cannot be separated from the social mission. Integrating commercial activities and social welfare is crucial in addressing societal issues in a sustainable manner [51].

Micro-economic entities undertaking business to improve current situations in their regions can be commercial entrepreneurs [22,23,52], individuals and families [52], households [24,39], and volunteers [39]. This could also be linked to corporate social responsibility (CSR) practices of commercial firms stimulated through direct incentives for executives [53,54]. Since our focus is on social entrepreneurship and a stakeholder approach, we will focus on how social enterprises as a micro-economic entity operate in a cross-border context. However, we do not exclude the other types of entities which sometimes can be found in local initiatives and in combination with social enterprises. Just like commercial enterprises, social enterprises are genuine businesses with a market-oriented approach $[2,43,46,49]$. In favor of sustainable cross-border cooperation is their cooperative-oriented approach [2], and the economic outcomes which are always subordinate to mission-driven social goals $[3,19,30,31,43,55]$.

We argue that social enterprises in border regions may benefit from economic and social cooperative arrangements with micro-economic entities and businesses partners but also with institutional organizations, such as Euregions. This may provide the social entrepreneur with access to resources needed for entering new markets and transaction costs. In return we envision a stronger involvement of local communities and citizens in cross-border cooperation which complements institutional EU cross-border cooperation. Therefore, we formulate the following assumption:

Assumption 4. Social entrepreneurship can be a form of cross-border cooperation contributing to local/regional economic and social development through commercial activities.

\section{Methodology}

\subsection{Introduction}

In order to meet the requirements of answering our research question and underlying assumptions, we built our research design among three dimensions, respectively. First, we distinguished between 
the concepts of institutional EU cross-border cooperation and social entrepreneurship. This was done by creating an expert group for each concept. Second, we distinguished between the institutional (top-down) approach and the micro-economic (bottom-up) approach by selecting experts from four different levels of governance: the EU, national, regional, and local level. And third, because our research question is general by nature and not geographically linked to a specific EU border region as such, we include experts from different countries and/or regions.

We did notice weaknesses in our design. For instance, the difference between the size and scope of the European institutional organizations compared to social enterprises organizations, which is expressed in the number of experts for both expert groups. Another weakness was the limitation in the variance of selected experts' countries and regions. Due to practical reasons, we were restricted to the current selection, although it would be interesting to have, for instance, Euregions and social entrepreneurs from the new EU Member States, e.g., eastern EU countries.

\subsection{Qualitative Design}

Our preferred method for explorative research is a qualitative approach [56]. In order to empirically test, explore, and improve our framework, we conducted 15 individual, semi-structured in-depth interviews with experts from both conceptual fields. It was expected to reach a sufficient level of saturation after 15 interviews, as indeed turned out to be the case. The experts were selected from the network of the researcher or newly approached because of the wish to have a person from the specific organization included as an expert. Experts were selected on their knowledge, experience, and involvement in top-down and/or bottom-up processes of social entrepreneurship and institutional EU cross-border cooperation.

The interviewed experts were spread over two expert groups. Expert Group 1 comprised experts from the institutional EU cross-border related organizations and Expert Group 2 comprised experts from social enterprise related organizations. Because of the difference in size and number between institutional EU organizations involved in cohesion policies and cross-border cooperation compared to social enterprise organizations, the distribution of interviewees across the two concepts is uneven: nine interviewees from the field of institutional EU cross-border cooperation and six interviewees from the field of social entrepreneurship.

Next to the selection of experts from institutional EU cross-border cooperation and social enterprise related organizations, a selection criterion was the multi-governance level on which the interviewees functions. Because our central research question brings together top-down and bottom-up processes, the selected experts come from different levels of governance. We had five experts at EU level, three experts at national level, four experts at regional level, and three experts at local level. This allowed us to gather data and insight from a political, policy, and operational point of view.

The experts were geographically spread over different countries (Belgium, England, France, Germany, Netherlands) and border regions (France-Belgium, France-Germany, France-Luxembourg, France-Spain, Germany-Netherlands, Netherlands-Belgium). Table 1 provides an overview of the experts, the distribution across the expert groups and their multi-governance level. 
Table 1. List of experts respondents.

\begin{tabular}{|c|c|c|c|c|c|}
\hline Organization & Abbreviation & Governance Level & Purpose Organization & Field of Expertise Interviewee & Expert Group \\
\hline $\begin{array}{l}1 \text { EU DG Regio, } \\
\text { Brussels (BE) }\end{array}$ & (DGR) & EU & $\begin{array}{l}\text { The Commission's } \\
\text { Directorate-General for } \\
\text { Regional and Urban Policy is } \\
\text { responsible for EU policy on } \\
\text { regions and cities. }\end{array}$ & $\begin{array}{l}\text { Interviewee coordinates the activities of the Border } \\
\text { Focal Point team of the DG Region. The Border Focal } \\
\text { Team supports cross-border interaction providing } \\
\text { political support for cross-border interactions that go } \\
\text { beyond mere financial support. }\end{array}$ & 1 \\
\hline $\begin{array}{l}2 \text { European } \\
\text { Parliament, } \\
\text { Brussels (BE) }\end{array}$ & $(\mathrm{EP})$ & $\mathrm{EU}$ & $\begin{array}{l}\text { The directly elected legislative } \\
\text { body of the European Union. }\end{array}$ & $\begin{array}{l}\text { Interviewee was Member of the European Parliament } \\
\text { until May } 2019 \text { and involved in the cohesion policy and } \\
\text { funding (Structural Funds). }\end{array}$ & 1 \\
\hline $\begin{array}{l}3 \text { House of } \\
\text { Representatives, } \\
\text { The Hague (NL) }\end{array}$ & (HOR) & National & $\begin{array}{l}\text { The House of Representatives } \\
\text { of the State's General. }\end{array}$ & $\begin{array}{l}\text { Interviewee is EU advisor for the Dutch House of } \\
\text { Representatives in the fields of agriculture, public } \\
\text { health education, and regional development. } \\
\text { In previous functions interviewee was involved in } \\
\text { European Regional Development Funding in the } \\
\text { Netherlands (ERDF) and the European Parliament as } \\
\text { advisor for the Structural Funds. }\end{array}$ & 1 \\
\hline $\begin{array}{l}4 \text { European Network } \\
\text { Rural Development, } \\
\text { Brussels (BE) }\end{array}$ & (ENRD) & $\mathrm{EU}$ & $\begin{array}{l}\text { Network organization for EU } \\
\text { Rural Development policy, } \\
\text { programs, projects, and other } \\
\text { initiatives. }\end{array}$ & $\begin{array}{l}\text { Interviewee is a policy analyst for the LEADER } \\
\text { program, which is part of the European Network for } \\
\text { Rural Development (ENRD). The ENRD is a policy } \\
\text { network organization with the aim to bring national } \\
\text { stakeholders together. }\end{array}$ & 1 \\
\hline $\begin{array}{l}5 \text { Association for } \\
\text { European Border } \\
\text { Regions }\end{array}$ & (AEBR) & $\mathrm{EU}$ & $\begin{array}{l}\text { Network organization on behalf } \\
\text { of the European border and } \\
\text { cross-border regions. }\end{array}$ & $\begin{array}{l}\text { Interviewee is a policy officer, mainly involved in the } \\
\text { collection of cross-border research and preparation of } \\
\text { policy documents for Brussels. }\end{array}$ & 1 \\
\hline $\begin{array}{l}6 \text { Mission } \\
\text { Opérationelle } \\
\text { Transfrontalière, } \\
\text { Paris (FR) }\end{array}$ & (MOT) & National & $\begin{array}{l}\text { NGO and network organization } \\
\text { promoting the interests of } \\
\text { French cross-border territories. }\end{array}$ & $\begin{array}{l}\text { Interviewee is a policy officer at the MOT. Interviewee is } \\
\text { in charge of studies and involved in the thematic teams } \\
\text { for mobility, environment, and social inclusion. }\end{array}$ & 1 \\
\hline $\begin{array}{l}7 \text { Euregio } \\
\text { Rhine-Waal, } \\
\text { Kleve (DE) }\end{array}$ & $(\mathrm{AMB})$ & Regional & $\begin{array}{l}\text { Euroregion to improve and } \\
\text { intensify cross-border } \\
\text { cooperation in the } \\
\text { Germany-Netherland border } \\
\text { region. }\end{array}$ & $\begin{array}{l}\text { Interviewee is ambassador for social entrepreneurship } \\
\text { in the Euroregion Rhine-Waal. As former mayor of two } \\
\text { border villages, interviewee has always been involved } \\
\text { in Euregion networks, activities, and issues. }\end{array}$ & 1 \\
\hline $\begin{array}{l}8 \text { Euregio } \\
\text { Rhine-Waal, } \\
\text { Kleve (DE) }\end{array}$ & $(\mathrm{ERW})$ & Regional & $\begin{array}{l}\text { Euroregion to improve and } \\
\text { intensify cross-border } \\
\text { cooperation in the } \\
\text { Germany-Netherland } \\
\text { border region. }\end{array}$ & $\begin{array}{l}\text { Interviewee is project coordinator of the Interreg project } \\
\text { BRESE (Border Regions in Europe for Social } \\
\text { Entrepreneurship). Interviewee was also involved in } \\
\text { the Interreg project KISS ME (Knowledge and } \\
\text { Innovation Strategies involving SME's). }\end{array}$ & 1 \\
\hline
\end{tabular}


Table 1. Cont

\begin{tabular}{|c|c|c|c|c|c|}
\hline Organization & Abbreviation & Governance Level & Purpose Organization & Field of Expertise Interviewee & Expert Group \\
\hline $\begin{array}{l}9 \text { Euregio } \\
\text { Meuse-Rhine, } \\
\text { Maastricht (NL) }\end{array}$ & (EMR) & Regional & $\begin{array}{l}\text { Euroregion to improve and } \\
\text { intensify cross-border } \\
\text { cooperation. }\end{array}$ & $\begin{array}{l}\text { Interviewee is the coordinator of the Euroregion EMR, } \\
\text { next to being major of a Belgium border village. } \\
\text { Interviewee is both politically and operationally } \\
\text { involved in cross-border cooperation activities of the } \\
\text { Meuse-Rhine region. }\end{array}$ & 1 \\
\hline $\begin{array}{l}10 \text { Social Enterprise } \\
\text { UK, London (UK) }\end{array}$ & (SEUK) & National & $\begin{array}{l}\text { Social enterprise network in } \\
\text { the UK. }\end{array}$ & $\begin{array}{l}\text { Interviewee is a policy and research officer at SE UK. } \\
\text { The aim is to give support (technical, policy advocacy) } \\
\text { to the members of SE UK, but also to the British Council. } \\
\text { Interviewee is involved in an Interreg project on social } \\
\text { entrepreneurship in the French-UK region. }\end{array}$ & 2 \\
\hline $\begin{array}{l}11 \text { Euclid Network, } \\
\text { The Hague (NL) }\end{array}$ & (EUCLID) & $\mathrm{EU}$ & $\begin{array}{l}\text { The European interest group } \\
\text { and network organization for } \\
\text { social entrepreneurs. }\end{array}$ & $\begin{array}{l}\text { Interviewee is a program manager at Euclid. Euclid } \\
\text { liaises with the EC, works on knowledge exchange and } \\
\text { exchange programs with other countries among all } \\
\text { other kinds of social enterprise support. }\end{array}$ & 2 \\
\hline $\begin{array}{l}12 \text { ConcertES, } \\
\text { Mont-Saint-Guibert, } \\
\text { Wallonia (BE) }\end{array}$ & $(\mathrm{CONC})$ & Regional & $\begin{array}{l}\text { Interest group representing the } \\
\text { regional social economy. }\end{array}$ & $\begin{array}{l}\text { Interviewee is the general secretary of ConcertES. } \\
\text { Interviewee is involved in the Interreg project VISES } \\
\text { that aims to validate social impact of social enterprises } \\
\text { in the Belgium-French region. }\end{array}$ & 2 \\
\hline $\begin{array}{l}13 \text { Haus } \\
\text { Freudenberg, } \\
\text { Kranenburg (DE) }\end{array}$ & (HFR) & Local & $\begin{array}{l}\text { Social enterprise that } \\
\text { rehabilitates, looks after, and } \\
\text { employs people with } \\
\text { disabilities. }\end{array}$ & $\begin{array}{l}\text { Interviewee is a social worker and participated in an } \\
\text { Interreg project Startkla(a)r with a Dutch partner to } \\
\text { implement cross-border solutions for emotionally } \\
\text { disabled people on the labor market. }\end{array}$ & 2 \\
\hline $\begin{array}{l}14 \text { Theodor-Bauer } \\
\text { Haus, Kleve (DE) }\end{array}$ & $(\mathrm{TBH})$ & Local & $\begin{array}{l}\text { Social enterprise supporting } \\
\text { people of all ages on their way } \\
\text { to work. }\end{array}$ & $\begin{array}{l}\text { Interviewees both work for the Theodor Brauer Haus on } \\
\text { the Interreg project 'Perspective } 360^{\prime} \text { that implements } \\
\text { innovations on the cross-border labor market. } \\
\text { The Theodor Brauer Haus is the Lead Partner. }\end{array}$ & 2 \\
\hline $\begin{array}{l}15 \text { Yumeko, } \\
\text { Amsterdam (NL) }\end{array}$ & (YUM) & Local & $\begin{array}{l}\text { Social enterprise in bedding } \\
\text { and bathroom linen. }\end{array}$ & $\begin{array}{l}\text { Interviewee is managing director of Yumeko. After } \\
\text { establishing their business on the Dutch market, } \\
\text { Yumeko implemented their social business model on } \\
\text { the German market. }\end{array}$ & 2 \\
\hline
\end{tabular}




\subsection{Data Collection}

We conducted 15 semi-structured interviews on an individual base, except for the interview with the TBH, which was done with two interviewees. Ten interviews were conducted face-to-face and five interviews were done by phone or Skype. We conducted the interviews following an interview protocol which was the same for both expert groups. The interview protocol was sent in advance to the interviewees and included the sections (1) introduction, (2) explanation of the research, (3) introduction of the interviewee, (4) rationales, (5) drivers, (6) characteristics, (7) objectives, and (8) closing. The interviews took between 30 and $60 \mathrm{~min}$ and were held in the period from August 2019 to November 2019. During the interviews, there was sufficient room to discuss specific cases or projects, which provided us with interesting additional data. We asked the interviewees for permission to record the interview, which was agreed by all interviewees. Due to technical problems, two interviews (EMR, MEP) were manually recorded through notes. Except for these, we transcribed all the other recorded interviews literally. Before we started analyzing the data, all transcriptions and notes were sent to the interviewees for correction and validation.

\subsection{Data Analysis}

To analyze the data, we use the method of a qualitative content analysis. Based upon the literature review we suggest two overarching typologies to structure the complementarity between the concepts of social entrepreneurship and institutionalized EU cross-border cooperation: (1) Drivers and (2) characteristics. While working on the literature review, we began by listing and coding attributes of drivers and characteristics for social entrepreneurship and institutional EU cross-border cooperation. As a result, we ended up with two listings of attributes grouped by the four assumptions (see Figure 1). We applied these attributes as units of measurement to analyze the empirical data.

To structure and analyze the gathered data, we applied a three stage coding method which uses (1) open coding, (2) axial coding, and (3) selective coding [57]. We analyzed the empirical results by counting and interpreting the attributes per assumption for all the interviews. Because the number of interviewees between Expert Group 1 and Expert Group 2 was uneven, we did not count how many times an attribute was mentioned, but only if an attribute was mentioned. Moreover, experts from Expert Group 1 could also mention attributes related to Expert Group 2 and vice versa.

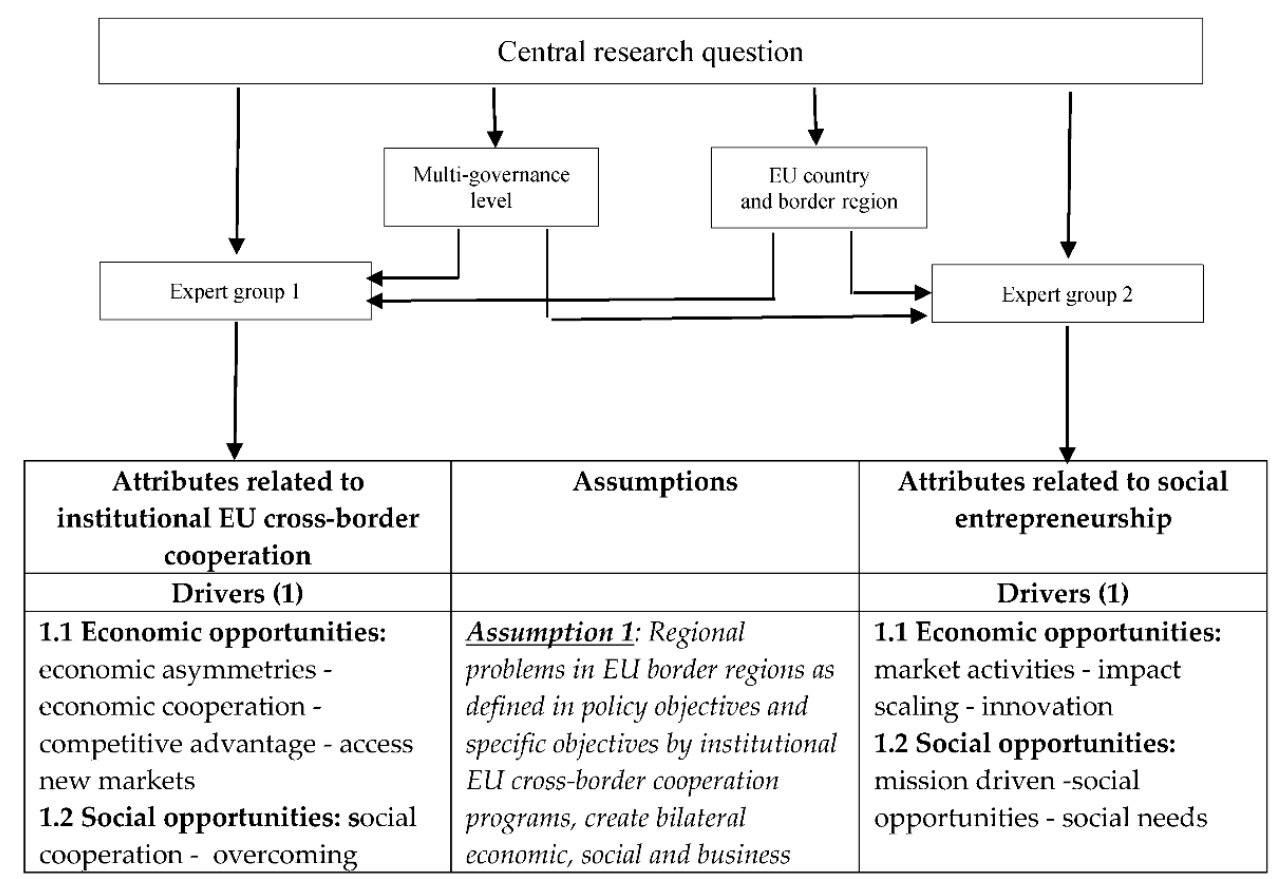

Figure 1. Cont. 


\begin{tabular}{|c|c|c|}
\hline $\begin{array}{l}\text { animosities - reducing violence - } \\
\text { neighborly communication } \\
\text { 1.3 Business opportunities: } \\
\text { small scale business cooperation } \\
\text { - entrepreneurial opportunities - } \\
\text { complementary resources - } \\
\text { entrepreneurial drive }\end{array}$ & $\begin{array}{l}\text { opportunities for social } \\
\text { entrepreneurship. }\end{array}$ & $\begin{array}{l}\text { 1.3 Business opportunities: } \\
\text { new business models - } \\
\text { combining resources - } \\
\text { financial sustainability }\end{array}$ \\
\hline Characteristics (2-4) & & Characteristics (2-4) \\
\hline $\begin{array}{l}\text { 2.1 Local embeddedness: } \\
\text { community sector - language } \\
\text { and mentality - bottom-up } \\
\text { activity - local entrepreneurship } \\
\text { 2.2 Local/regional daily life } \\
\text { problems: daily life aspects - } \\
\text { daily life problems - quality of } \\
\text { life - conflict mitigation }\end{array}$ & $\begin{array}{l}\text { Assumption 2: The local } \\
\text { embeddedness of social } \\
\text { entrepreneurship and } \\
\text { institutional EU cross-border } \\
\text { cooperation mutually reinforce } \\
\text { each other, thereby decreasing } \\
\text { local/regional daily life problems. }\end{array}$ & $\begin{array}{l}\text { 2.1 Local embeddedness: local } \\
\text { communities - traditions and } \\
\text { sensitivities - citizens } \\
\text { initiatives - local concerns- } \\
\text { bottom-up efforts } \\
2.2 \text { Local/regional daily life } \\
\text { problems: local problems - } \\
\text { local needs - human well- } \\
\text { being }\end{array}$ \\
\hline $\begin{array}{l}\text { 3.1 Social capital: trust - } \\
\text { reciprocity - interdependency - } \\
\text { familiarity } \\
\text { 3.2 Local/regional daily life } \\
\text { problems: daily life aspects - } \\
\text { daily life problems - quality of } \\
\text { life - conflict mitigation }\end{array}$ & $\begin{array}{l}\text { Assumption 3: The exchange of } \\
\text { social capital between } \\
\text { institutional EU cross-border } \\
\text { cooperation and social } \\
\text { entrepreneurship decrease } \\
\text { local/regional daily life problems. }\end{array}$ & $\begin{array}{l}\text { 3.1 Social capital: trust - } \\
\text { reciprocity -solidarity - social } \\
\text { value - social networks } \\
\text { 3.2 Local/regional daily life } \\
\text { problems: local problems - } \\
\text { local needs - human well- } \\
\text { being }\end{array}$ \\
\hline $\begin{array}{l}\text { 4.1 Commercial activities: } \\
\text { entrepreneurial activities - } \\
\text { market knowledge - new } \\
\text { business contacts - trading } \\
\text { activities - entrepreneurial } \\
\text { cultures } \\
4.2 \text { Economic and social } \\
\text { development: economic } \\
\text { development - social } \\
\text { development - environmental } \\
\text { conservation - regional } \\
\text { development - economic growth }\end{array}$ & $\begin{array}{l}\text { Assumption 4: Social } \\
\text { entrepreneurship can be a form of } \\
\text { cross-border cooperation } \\
\text { contributing to locallregional } \\
\text { economic and social development } \\
\text { through commercial activities. }\end{array}$ & $\begin{array}{l}\text { 4.1 Commercial activities: } \\
\text { market activities - profit - self } \\
\text { sustainable - repay } \\
\text { investments } \\
4.2 \text { Economic and social } \\
\text { development: economic goals } \\
\text { - social goals - ecological goals } \\
\text { - economic growth - } \\
\text { sustainable prosperity }\end{array}$ \\
\hline
\end{tabular}

Figure 1. Coding scheme.

\section{Empirical Results}

In this and the next section we will present the empirical result of the interviews both in text, and in tables (Tables 2-5). We report on the empirical results per expert group. This provides a better insight on how both expert groups differ in their opinion when it comes to the propositions. Because top-down and bottom-up processes are part of our research question, we take regular notice of the governance level of the interviewee.

Table 2. Empirical results Assumption 1.

\begin{tabular}{|c|c|c|c|c|c|c|}
\hline \multirow{3}{*}{$\begin{array}{l}\text { Expert } \\
\text { Governance } \\
\text { Level }\end{array}$} & \multicolumn{6}{|c|}{$\begin{array}{c}\text { Assumption 1: Regional Problems in EU Border Regions Create Bilateral (1) Economic, (2) Social } \\
\text { Opportunities, and (3) Business Opportunities through a Bottom-Up and Micro-Economic Approach of EU } \\
\text { Cross-Border Cooperation. }\end{array}$} \\
\hline & \multicolumn{3}{|c|}{ Expert Group 1: EU Political and Policy Experts } & \multicolumn{3}{|c|}{ Expert Group 2: Social Enterprise Experts } \\
\hline & $\begin{array}{c}\text { Economic } \\
\text { Opportunities }\end{array}$ & $\begin{array}{c}\text { Social } \\
\text { Opportunities }\end{array}$ & $\begin{array}{c}\text { Business } \\
\text { Opportunities }\end{array}$ & $\begin{array}{c}\text { Economic } \\
\text { Opportunities }\end{array}$ & $\begin{array}{c}\text { Social } \\
\text { Opportunities }\end{array}$ & $\begin{array}{c}\text { Business } \\
\text { Opportunities }\end{array}$ \\
\hline EU & $\begin{array}{c}\text { Economic } \\
\text { asymmetries } \\
\text { Economic cooperation } \\
\text { Access new markets } \\
\text { Impact scaling }{ }^{1}\end{array}$ & $\begin{array}{l}\text { Social } \\
\text { cooperation } \\
\text { Overcoming } \\
\text { animosities }\end{array}$ & $\begin{array}{l}\text { Small scale business } \\
\text { cooperation } \\
\text { Entrepreneurial } \\
\text { opportunities } \\
\text { Entrepreneurial drive } \\
\text { Complementary } \\
\text { resources }\end{array}$ & $\begin{array}{l}\text { Market } \\
\text { activities } \\
\text { Competitive } \\
\text { advantage }\end{array}$ & & $\begin{array}{l}\text { New business } \\
\text { models } \\
\text { Combining } \\
\text { resources }\end{array}$ \\
\hline
\end{tabular}


Table 2. Cont.

\begin{tabular}{|c|c|c|c|c|c|c|}
\hline \multirow{3}{*}{$\begin{array}{l}\text { Expert } \\
\text { Governance } \\
\text { Level }\end{array}$} & \multicolumn{6}{|c|}{$\begin{array}{l}\text { Assumption 1: Regional Problems in EU Border Regions Create Bilateral (1) Economic, (2) Social } \\
\text { Opportunities, and (3) Business Opportunities through a Bottom-Up and Micro-Economic Approach of EU } \\
\text { Cross-Border Cooperation. }\end{array}$} \\
\hline & \multicolumn{3}{|c|}{ Expert Group 1: EU Political and Policy Experts } & \multicolumn{3}{|c|}{ Expert Group 2: Social Enterprise Experts } \\
\hline & $\begin{array}{c}\text { Economic } \\
\text { Opportunities }\end{array}$ & $\begin{array}{c}\text { Social } \\
\text { Opportunities }\end{array}$ & $\begin{array}{c}\text { Business } \\
\text { Opportunities }\end{array}$ & $\begin{array}{l}\text { Economic } \\
\text { Opportunities }\end{array}$ & $\begin{array}{c}\text { Social } \\
\text { Opportunities }\end{array}$ & $\begin{array}{c}\text { Business } \\
\text { Opportunities }\end{array}$ \\
\hline National & $\begin{array}{c}\text { Economic } \\
\text { asymmetries } \\
\text { Economic cooperation } \\
\text { Competitive } \\
\text { advantage } \\
\text { Access new markets }\end{array}$ & $\begin{array}{l}\text { Social } \\
\text { cooperation } \\
\text { Neighborly } \\
\text { communication }\end{array}$ & $\begin{array}{l}\text { Small scale business } \\
\text { cooperation } \\
\text { Entrepreneurial } \\
\text { opportunities } \\
\text { Entrepreneurial drive } \\
\text { Complementary } \\
\text { resources }\end{array}$ & $\begin{array}{c}\text { Market } \\
\text { activities }\end{array}$ & $\begin{array}{l}\text { Social needs } \\
\text { Overcoming } \\
\text { animosities }^{2}\end{array}$ & $\begin{array}{l}\text { Entrepreneurial }^{1} \\
\text { opportunities }^{2} \\
\text { New business } \\
\text { models }\end{array}$ \\
\hline Regional & $\begin{array}{c}\text { Economic } \\
\text { asymmetries } \\
\text { Economic cooperation } \\
\text { Competitive } \\
\text { advantage } \\
\text { Access new markets }\end{array}$ & $\begin{array}{l}\quad \text { Social } \\
\text { cooperation } \\
\text { Overcoming } \\
\text { animosities } \\
\text { Neighborly } \\
\text { communication }\end{array}$ & $\begin{array}{l}\text { Small scale business } \\
\text { cooperation } \\
\text { Entrepreneurial } \\
\text { opportunities } \\
\text { Entrepreneurial drive } \\
\text { Complementary } \\
\text { resources }\end{array}$ & $\begin{array}{c}\text { Market } \\
\text { activities }\end{array}$ & $\begin{array}{c}\text { Mission } \\
\text { driven } \\
\text { Social } \\
\text { cooperation } \\
\text { Social needs }\end{array}$ & $\begin{array}{l}\text { New business } \\
\text { models }\end{array}$ \\
\hline Local & $\begin{array}{l}\text { Economic } \\
\text { asymmetries } \\
\text { Access new markets }\end{array}$ & $\begin{array}{c}\text { Social } \\
\text { cooperation } \\
\text { Neighborly } \\
\text { communication } \\
\text { Social } \\
\text { needs }{ }^{1} \\
\text { Mission } \\
\text { driven }^{1} \\
\text { Social } \\
\text { opportunities }^{1}\end{array}$ & $\begin{array}{c}\text { Small scale business } \\
\text { cooperation } \\
\text { Entrepreneurial } \\
\text { opportunities } \\
\text { Combining }{ }^{1} \\
\text { resources }\end{array}$ & $\begin{array}{l}\text { Impact } \\
\text { scaling } \\
\text { Market } \\
\text { activities } \\
\text { Economic } \\
\text { asymmetries } \\
\text { Economic } \\
\text { cooperation }\end{array}$ & $\begin{array}{c}\text { Mission } \\
\text { driven } \\
\text { Neighborly } \\
\text { communication }{ }^{2} \\
\text { Social } \\
\text { cooperation }{ }^{2} \\
\text { Social } \\
\text { problems }\end{array}$ & $\begin{array}{l}\text { New business } \\
\text { models } \\
\text { Small scale } \\
\text { business } \\
\text { cooperation }^{2}\end{array}$ \\
\hline
\end{tabular}

${ }^{1}$ Attributes coming from social entrepreneurship; ${ }^{2}$ Attributes coming from institutional EU cross-border cooperation.

Table 3. Empirical results Assumption 2.

\begin{tabular}{|c|c|c|c|c|}
\hline \multirow{3}{*}{$\begin{array}{l}\text { Expert } \\
\text { Governance } \\
\text { Level }\end{array}$} & \multicolumn{4}{|c|}{$\begin{array}{l}\text { Assumption 2: The (1) Local Embeddedness of Both Social Entrepreneurship and cRoss-Border } \\
\text { Cooperation Mutually Reinforce Each Other, Thereby Decreasing (2) Local/Regional Daily } \\
\text { Life Problems. }\end{array}$} \\
\hline & \multicolumn{2}{|c|}{ Expert Group 1: EU Political and Policy Experts } & \multicolumn{2}{|c|}{ Expert Group 2: Social Enterprise Experts } \\
\hline & Local Embeddedness & $\begin{array}{l}\text { Daily Life } \\
\text { Problems }\end{array}$ & Local Embeddedness & $\begin{array}{l}\text { Daily Life } \\
\text { Problems }\end{array}$ \\
\hline EU & $\begin{array}{l}\text { Community sector } \\
\text { Local entrepreneurship } \\
\text { Language and mentality } \\
\text { Bottom-up activity }\end{array}$ & $\begin{array}{l}\text { Daily life aspects } \\
\text { Quality of life }\end{array}$ & $\begin{array}{c}\text { Local communities } \\
\text { Local entrepreneurship } 2\end{array}$ & $\begin{array}{l}\text { Local problems } \\
\text { Local needs }\end{array}$ \\
\hline National & $\begin{array}{l}\text { Community sector } \\
\text { Language and mentality } \\
\text { Bottom-up activity } \\
\text { Local entrepreneurship } \\
\text { Citizens initiatives }{ }^{1}\end{array}$ & Quality of life & $\begin{array}{l}\text { Local communities } \\
\text { Local concerns } \\
\text { Bottom-up efforts } \\
\text { Citizens initiatives }\end{array}$ & $\begin{array}{l}\text { Local problems } \\
\text { Local needs } \\
\text { Human well-being }\end{array}$ \\
\hline Regional & $\begin{array}{l}\text { Community sector } \\
\text { Language and mentality } \\
\text { Bottom-up activity } \\
\text { Local entrepreneurship } \\
\text { Citizens initiatives }{ }^{1}\end{array}$ & $\begin{array}{l}\text { Daily life aspects } \\
\text { Quality of life }\end{array}$ & $\begin{array}{l}\text { Local entrepreneurship }{ }^{2} \\
\text { Citizens initiatives }\end{array}$ & $\begin{array}{l}\text { Local problems } \\
\text { Local needs } \\
\text { Human well-being }\end{array}$ \\
\hline Local & $\begin{array}{l}\text { Community sector } \\
\text { Language and mentality } \\
\text { Local entrepreneurship } \\
\text { Bottom-up activity }\end{array}$ & Quality of life & $\begin{array}{l}\text { Bottom-up effort } \\
\text { Local communities } \\
\text { Traditions and sensitivities } \\
\text { Community sector }{ }^{2} \\
\text { Language and mentality }^{2} \\
\text { Local entrepreneurship }^{2}\end{array}$ & $\begin{array}{l}\text { Local problems } \\
\text { Local needs } \\
\text { Human well-being }\end{array}$ \\
\hline
\end{tabular}

\footnotetext{
${ }^{1}$ Attributes coming from social entrepreneurship; ${ }^{2}$ Attributes coming from institutional EU cross-border cooperation.
} 
Table 4. Empirical results Assumption 3.

\begin{tabular}{|c|c|c|c|c|}
\hline \multirow{3}{*}{$\begin{array}{l}\text { Expert } \\
\text { Governance } \\
\text { Level }\end{array}$} & \multicolumn{4}{|c|}{$\begin{array}{c}\text { Assumption 3: Simultaneous and Bilateral Utilization and Creation of (1) Social Capital by } \\
\text { Social Entrepreneurship and Cross-Border Cooperation Decrease (2) Local/Regional Daily } \\
\text { Life Problems through Interdependent Processes of Social Entrepreneurship and } \\
\text { Cross-Border Cooperation. }\end{array}$} \\
\hline & \multicolumn{2}{|c|}{ Expert Group 1: Political and Policy Experts } & \multicolumn{2}{|c|}{ Expert Group 2: Social Enterprise Experts } \\
\hline & Social Capital & Daily Life Problems & Social Capital & Daily Life Problems \\
\hline EU & $\begin{array}{l}\text { Trust } \\
\text { Reciprocity } \\
\text { Interdependency } \\
\text { Familiarity }\end{array}$ & $\begin{array}{l}\text { Daily life aspects } \\
\text { Conflict mitigation } \\
\text { Quality of life }\end{array}$ & $\begin{array}{c}\text { Trust } \\
\text { Reciprocity }\end{array}$ & Conflict mitigation ${ }^{1}$ \\
\hline National & $\begin{array}{l}\text { Trust } \\
\text { Reciprocity } \\
\text { Interdependency } \\
\text { Familiarity }\end{array}$ & Quality of life & $\begin{array}{l}\text { Trust } \\
\text { Reciprocity } \\
\text { Interdependency } \\
\text { Familiarity } \\
1\end{array}$ & $\begin{array}{l}\text { Local problems } \\
\text { Local needs } \\
\text { Human well-being }\end{array}$ \\
\hline Regional & $\begin{array}{c}\text { Trust } \\
\text { Reciprocity } \\
\text { Interdependency } \\
\text { Familiarity }\end{array}$ & $\begin{array}{l}\text { Daily life aspects } \\
\text { Daily life problems }\end{array}$ & $\begin{array}{c}\text { Trust } \\
\text { Social networks }\end{array}$ & \\
\hline Local & $\begin{array}{c}\text { Trust } \\
\text { Reciprocity } \\
\text { Interdependency } \\
\text { Familiarity }\end{array}$ & $\begin{array}{c}\text { Daily life problems } \\
\text { Quality of life }\end{array}$ & $\begin{array}{c}\text { Trust } \\
\text { Reciprocity } \\
\text { Familiarity }\end{array}$ & $\begin{array}{c}\text { Daily life aspects }{ }^{1} \\
\text { Daily life problems } \\
\text { Quality of life } \\
{ }^{1} \\
\text { Local problems } \\
\text { Local needs } \\
\text { Human well-being }\end{array}$ \\
\hline
\end{tabular}

Table 5. Empirical results Assumption 4.

\begin{tabular}{|c|c|c|c|c|}
\hline \multirow[b]{3}{*}{$\begin{array}{l}\text { Expert } \\
\text { Governance } \\
\text { Level }\end{array}$} & \multicolumn{4}{|c|}{$\begin{array}{l}\text { Assumption 4: Regional Cross-Border Social Entrepreneurship Can be a Form of Cross-Border } \\
\text { Cooperation Contributing to Local/Regional Economic and Social Development through } \\
\text { Commercial Activities. }\end{array}$} \\
\hline & \multicolumn{2}{|c|}{ Expert Group 1: Political and Policy Experts } & \multicolumn{2}{|c|}{ Expert Group 2: Social Enterprise Experts } \\
\hline & Commercial Activities & $\begin{array}{l}\text { Economic and Social } \\
\text { Development }\end{array}$ & Commercial Activities & $\begin{array}{l}\text { Economic and } \\
\text { Social } \\
\text { Development }\end{array}$ \\
\hline $\mathrm{EU}$ & $\begin{array}{l}\text { Entrepreneurial activities } \\
\text { New business contracts } \\
\text { Trading activities } \\
\text { Entrepreneurial cultures } \\
\text { Market knowledge }\end{array}$ & $\begin{array}{l}\text { Economic development } \\
\text { Social development } \\
\text { Regional development }\end{array}$ & $\begin{array}{l}\text { Entrepreneurial activities }{ }^{1} \\
\text { Entrepreneurial cultures }{ }^{1}\end{array}$ & $\begin{array}{l}\text { Economic growth } \\
\text { Social goals } \\
\text { Regional } \\
\text { development }^{1}\end{array}$ \\
\hline National & $\begin{array}{l}\text { Entrepreneurial activities } \\
\text { Trading activities }\end{array}$ & $\begin{array}{l}\text { Economic development } \\
\text { Social development } \\
\text { Regional development } \\
\text { Economic growth } \\
\text { Social development }\end{array}$ & $\begin{array}{c}\text { Profit } \\
\text { Self-sustainable } \\
\text { Trading activities }^{1} \\
\text { Entrepreneurial activities }^{1} \\
\text { Market knowledge }^{1} \\
\text { Entrepreneurial cultures }^{1}\end{array}$ & $\begin{array}{l}\text { Sustainable } \\
\text { prosperity } \\
\text { Economic growth } \\
\text { Social goals }\end{array}$ \\
\hline Regional & Entrepreneurial cultures & $\begin{array}{l}\text { Economic development } \\
\text { Social development } \\
\text { Regional development } \\
\text { Economic growth }\end{array}$ & $\begin{array}{c}\text { Market activities } \\
\text { Profit } \\
\text { Self-sustainable } \\
\text { Entrepreneurial cultures }{ }^{1}\end{array}$ & $\begin{array}{l}\text { Economic goals } \\
\text { Social goals } \\
\text { Ecological goals }\end{array}$ \\
\hline Local & $\begin{array}{l}\text { Entrepreneurial activities } \\
\text { New business contracts } \\
\text { Entrepreneurial cultures }\end{array}$ & $\begin{array}{c}\text { Environmental } \\
\text { conversation } \\
\text { Social development } \\
\text { Regional development }\end{array}$ & $\begin{array}{c}\text { Profit } \\
\text { Market activities } \\
\text { Self-sustainable } \\
\text { Market knowledge }{ }^{1} \\
\text { New business contracts }{ }^{1}\end{array}$ & $\begin{array}{l}\text { Economic goals } \\
\text { Social goals } \\
\text { Sustainable } \\
\text { prosperity }\end{array}$ \\
\hline
\end{tabular}

\footnotetext{
${ }^{1}$ Attributes coming from institutional EU cross-border cooperation.
} 


\subsection{Expert Group 1}

\subsubsection{Drivers: Economic Opportunities, Social Opportunities, and Business Opportunities}

Interviewees of Expert Group 1 at all governance levels identify economic opportunities in cross-border markets for social entrepreneurs. At the EU level, operating nearby the border is seen as an opportunity to access new markets, but interviewees at EU level share different visions. For instance, the MEP explains that entrepreneurs could enlarge their field of play, the DGR emphasizes the importance of cooperation with a partner across the border, and the ENRD envisions cooperation as a potential form of scaling up the social business. The experts on the national and regional level (MOT and ERW, respectively) explain how local social entrepreneurs are stimulated to participate in cross-border Interreg projects and work together with local communities. Economic asymmetries such as imperfection of the labor market, price differences in health care and environmental problems are mentioned as triggers for social entrepreneurs to reach out across the border. The interviewee at the local level (AMB) was less positive towards economic opportunities across the border. Economic cooperation and competitive advantages are not directly seen as an opportunity for cross-border cooperation. The AMB agrees on the existence of these opportunities but was more critical because of language barriers that prevent local entrepreneurs from bilateral cooperation.

The interviewees from Expert Group 1 associate social opportunities mostly with social cooperation, which is seen as an important asset of cross-border cooperation at all governance levels. Interviewees mention different opportunities for social cooperation, such as the importance of social inclusion in rural areas (ENRD), connectivity through common natural resources (ENRD), or a stronger sense of belonging between people that live in the same cross-border region compared to people elsewhere in their own country (MOT, ERW). Overcoming animosities is still seen as a hurdle to be taken in border regions. On EU level, the DGR and the ENRD endorse that due to history and heritage, trust building in border regions is still essential. Social entrepreneurship could play a role in the mitigation of distrust through bilateral cooperation with local communities. On national level, the MOT gave two examples how social entrepreneurship impacts border regions: (1) In the France-Spain Basque region, an old station was turned into a social meeting place with a real cross-border vision; and (2) in the German-France border region, social entrepreneurs in smaller cities use the vacancy of retail properties because of the last crisis to start new businesses.

Interviewees endorse neighborly communication as an unconditional attribute of social opportunities for working together with your cross-border neighbor. On EU level, neighborly communication is less seen as an issue, maybe because the interviewees take part in all kinds of consultative bodies. On national, regional, and local level neighborly communication is increasingly seen as necessary for establishing cross-border cooperation. Interviewees (AMB, EWR, HOR, and MOT) mention how communicating and sharing possible solutions for local problems with your bilateral neighbor could create real connectedness. In relation to social entrepreneurship, however, interviewees expect a pro-active entrepreneurial role in networking and partnering. Interviewees mention language as an issue that may prevent entrepreneurs from cooperating across the border. The AMB, who operates very locally in his region, takes the social opportunities a step further by mentioning attributes from social entrepreneurship with a real bottom-up approach: identify the social needs of people, search for mission driven solutions, and create social opportunities.

All interviewees from Expert Group 1 are positive about business opportunities which may contribute to processes of cross-border cooperation. Thereby, the entrepreneurial drive is welcomed as a positive factor to solve local or regional problems through a social business. Two interviewees on EU level (DGR, MEP), however, explain that cross-border cooperation is a long-term effort not based on pure market thinking, but on trust building and self-learning ability of the entrepreneur. The MEP explains how innovation should be brought to the region by the EC as a complementary resource; entrepreneurs should implement ideas and project results from other European programs, such as H2020, but that this is not happening today. On the national level the interviewee of the 
HOR pleads for more room in the ECs' Common Provision Regulation for small scale businesses, administrative rules, and non-competition clauses. The ERW endorses that there is a lot of engagement amongst entrepreneurs and that social entrepreneurial activities could affect people's daily life. As a strong advocate for social businesses, the AMB came up with different examples of opportunities to improve food quality, health, and clean air in the region.

“... If you look at the goal of the Interreg program and also the strategic initiatives, they can be very much aligned with what social enterprises work on. So I think, one of the goals Interreg is social cohesion and that social enterprises are perfect alike." (ERW)

\subsubsection{Characteristics: Local Embeddedness, Social Capital, and Commercial Activities}

The first characteristic we examine is local embeddedness. Interviewees from Expert Group 1 on all levels are unanimous on the necessity of local embeddedness in relation to solving daily life local problems. On EU level the DGR states that the current top-down processes to foster regional development, such as Interreg, are well embedded in regional governance structures and democratic processes. The AEBR argues that the community feeling of local entrepreneurship is very good, but that the human factor is often an obstacle because of language issues or a lack of trust. In institutional cross-border cooperation processes the human factor plays less a role and the focus is more on policy and regulation. In contradiction to this point of view, the interviewee of the MOT states very clearly that the experts on the ground are the local people. By taking the first move, local organizations and social entrepreneurs can take along civil society, municipalities, and the local business sector in processes of cooperation (MOT, ERW). The function of local embeddedness also affects how regional societal problems, that bear strong resemblance across the border, are dealt with locally. An example of this was given by the MOT (FR) and concerns environmental and ecological problems in the Strassbourg-Ortenau region. Within the context of climate change, these local problems are a driver for bottom-up cross-border cooperation. Citizens in this region are involved in building strategies to tackle these problems. The AMB explains how local problems are often intertwined. For instance, intensive livestock farming that causes environmental problems in the region. More interest in locally produced food and health issues could contribute to decrease these environmental problems.

The second characteristic we examine was the use and creation of social capital. We discuss three elements of social capital: trust, interdependency, and reciprocity. Trust was the most mentioned and discussed element compared to interdependency and reciprocity. Although the degree of trust/distrust seems to vary per EU border region, all interviewees emphasize the necessity of mutual trust between actors in cross-border cooperation and thus, the importance of trust building. Interviewees mention how many border people still fear their neighbors on the other side of the border. On EU level, the DGR explained that after 25 years of Interreg, the EC found that one of the most important lessons learned was that trust building is a key element in cross-border cooperation. The MEP explained trust as an aspect of cooperation between EU Member States and related trust to the European Grouping Territorial Cooperation (EGTC). This instrument was implemented by the EC in 2016 to establish cross-border cooperation territorial groupings as a legal entity. Illustrative with regards to the different regional perception of trust is how the interviewee of the EMR experiences no distrust at all in the Euregion Meuse-Rhine while the AMB mentions how it took 75 years to create a 'normal level of trust' in the Euregion Rhine-Waal between Germany and the Netherlands (AMB).

The use and creation of social capital might be a pitfall as well. The moment that a level of trust in a certain region is low, it is not possible for a social enterprise to use trust until it is created. On EU level interviewees (AEBR, DGR) argue that this may result in high transaction costs for establishing cross-border cooperation by a social entrepreneur. Trust may also be the reason why the same kinds of people engage with each other in cross-border cooperation. For instance, innovators cooperate with innovators and never with followers. Another remark made by DGR was that differences between people can be mitigated through small scale initiatives. The DG Regio implemented people-to-people 
projects as a tool to create more contacts, e.g., a football match across the border, student exchanges, and intercultural events.

"The more that you have the trust element, the more that you have the empowerment, the more that you have the embeddedness, the more that you have social entrepreneurship with the guy on the other side of the border." (DGR)

The third characteristic we examined is the commercial activities within border regions which we link to the achievement of social and economic development. On EU level the interviewee of the MEP pleads for a triangulate approach to stimulate local entrepreneurship: territorial areas-people-research and development. The interviewee of the ENRD explains how entrepreneurial activities contribute to local development by creating local business networks which lead to trading activities and the establishment of new business contracts. These entrepreneurial activities also include social initiatives. The interviewee of the DGR places a critical remark by arguing that social entrepreneurs might be driven by their own local development and social profit, which will not always benefit regional cross-border cooperation. The interviewee of the EMR argues that the market is definitely there, but that the involvement of social enterprises in the regional economy is rather low. And as a result, the creation of impact is seen as relatively low. In the Euregion Rhine-Waal regular bi-lateral business meetings take place, which are seen as very important by the interviewees of the AMB and ERW. These kinds of network events are important, because entrepreneurs are often positive about opportunities for setting up their business across the border, but without having a clue how to do this.

\subsection{Expert Group 2}

\subsubsection{Drivers: Economic Opportunities, Social Opportunities, and Business Opportunities}

Interviewees from Expert Group 2 on the EU, national, and regional level expect limited opportunities for social entrepreneurship in EU cross-border regions. Social entrepreneurs with the ambition to extend their businesses need to find markets with similar social problems and these markets do not always exist in border regions (EUCL, SEUK). The interviewee of EUCL states that social enterprises may have competitive advantage when comes to revitalizing rural areas also in border regions. The interviewees on the local level, on the contrary, are convinced of economic opportunities. Interviewees from TBH and HFR experienced how a combination of economic asymmetries and economic/social cooperation have led to successful cross-border cooperation. In the Euregion Rhein-Waal an Interreg project has successfully been implemented to solve bilateral imbalances on the labor market. The TBH was one of the partners in this project which will be rolled out in other regions as well. And the interviewee of HFR participated in a similar cross-border cooperation project for disabled people, also in the Euregion Rhine-Waal. The interviewee of YUM operates in quite a different setting compared to HFR and TBH. YUM is selling sustainable consumer bath and bed textile products and implemented its social business model on the German market. The interviewee agrees that there are opportunities but emphasizes that there are many restrictions in technical rules and regulations.

"Thus, we cannot enter the British market. As an entrepreneur you are confronted with all local rules and regulations ... The great diversity of the EU is a gift for entrepreneurial opportunities, but also very challenging one." (YUM)

The interviewee at the EU level did not mention any social opportunities for social entrepreneurship in a cross-border setting. On the national and regional level interviewees see social needs, such as addressing social exclusion and closing of local amenities, as fertile ground for social entrepreneurship, also in a cross-border setting. On national level the interviewee of SEUK explains how social entrepreneurship may improve a particular community through social inclusion and how this could help to overcome animosities. In the context of social cooperation, the interviewee from CONC mentions a project with the aim to clean up a river that crosses the Belgium-France border, with the effort of people with a distance to the labor market. Similar to economic opportunities, the interviewees 
of the local level are more convinced of social opportunities compared to the other levels. Mission driven models for cooperation could work very well in a bilateral setting and sharing useful instruments with your bilateral partner is seen as very effective (HFR, TBH). Thereby, the TBH is very positive on how the cooperation with partners from the neighboring country and the institutional partner (Euregion ERW) complement each other with their expertise.

Interviewees in Expert Group 2 are more aligned when it comes to business opportunities. Overall, the interviewees see social entrepreneurs as creative and innovative in organizing their businesses, as well as inspiring for other entrepreneurs. On the EU level the EUCL mentions how new business models may be an option for reaching out across the regional or local border for social entrepreneurs. As an example, the EUCL mentions social franchising, a model which is already applied by social entrepreneurs operating on the international market such as Happy Tosti. The interviewee of SEUK observes a new trend in local community ownership and how for example the Scottish government stimulates this to make communities on islands more self-supportive. In a bilateral setting this could contribute to strong social cohesion. The interviewee of YUM explained how their social business model for selling sustainable bed and bath textiles has been implemented in Germany. Although YUM is not a genuine example of regional cross-border cooperation, YUM still strongly stands as an example case of how a business model can be implemented in a neighboring country. There by, YUM buys fair-trade cotton from farmers outside the EU, but the filling of the quilts for the German market is produced by sustainable goose farmers in Germany which a good example of social-economic cooperation.

\subsubsection{Characteristics: Local Embeddedness, Social Capital, and Commercial Activities}

At EU and national level, the interviewees of the EUCL and SEUK mention the importance of being embedded in local governance structures if you want to solve local problems. The EUCL observes that it is much more difficult for social entrepreneurs to establish their businesses across the border compared to commercial businesses because of rules and regulations. Moreover, opportunities through cooperation with EU institutions often remain unnoted by social entrepreneurs. SEUK refers to local community ownership in relation to local embeddedness in governance structures. On the regional level CONC argues that citizens in a bilateral setting are not always aware of their shared needs and that this could be improved by informing them. On the local level, interviewees are confronted with local traditions and sensitivities next to language and mentality. For instance, the TBH mentions the difference between Germany and the Netherlands in behavioral manners on the work floor. And the disabled employees of HFR produce specifically for the local market. YUM places local embeddedness in a slightly different perspective. They faced challenges on local technical safety demands, such as fire-resistant materials, but also on the taste of consumers and the how consumers are used to buy their quilts, e.g., in a shop versus on-line buying.

Interviewees from all levels relate trust, reciprocity, and interdependency to different aspects of daily life problems. On the EU level the interviewee of EUCL explains that, for a long period, countries were not always on good terms. Social entrepreneurship could bring an important contribution to strengthen social cohesion between countries and people. As an example, the EUCL mentions the animosities between the new EU countries in Eastern Europe in the recent past and how the number of social enterprises grow in these countries and regions, and how they work together with the Interreg programs if possible. An example of reciprocity was given by SEUK as social entrepreneurship serves the interest of the community, it expects some kind of support in return from the community, but also from local authorities, e.g., support, voluntary work, payment of a higher price. YUM experiences an extra dimension of trust through consumers that want to justify their sustainable purchase and rely on the sustainability claim of the brand they are buying.

The interviewees of Expert Group 2 are unanimous on how commercial activities could contribute to economic growth and social development of the regions. But there are different opinions on the nature of commercial activities. Both EUCL and SEUK refer to how the Scottish government stimulates social enterprises to reach out across the Scottish-English border, but also to the rest 
of Europe. But SEUK emphasizes that the Scottish government wants social enterprises to be resilient and self-reliant, especially on the Scottish islands where more community-based enterprises can be found. The aim is to have social enterprises to support themselves. On the national, regional, and local level, the interviewees mention profit and self-sustainability as important assets of social entrepreneurship in relation to economic and social goals. In the UK social entrepreneurship can be found in almost every sector of the economy. Mswaka et al., 2015 [46] confirm this in their case study for South Yorkshire. Although a social enterprise may not always have the size of a critical mass in its specific sector, a social enterprise can create positive impact on a small scale for a specific aim.

Commercial activities in neighboring countries may lead to high transaction costs. YUM explains how the European diversity is both an opportunity and a problem for the business case of the social value proposition. Because a social enterprise cannot devaluate its social mission, transaction costs may become a barrier for commercial activities in competition with a commercial enterprise. The interviewee of HFR explains how HFR searched for long term business contracts with large commercial customers in the region, to secure their trading activities. HFR operates mainly at the German side of the border for their commercial activities but cooperates with Dutch partners when it comes to the supporting of disabled people and education. Although the cross-border cooperation activities of HFR and the TBH are quite similar and within the same region, their opinion on the creation of impact differs. The interviewee of HFR explains that their impact in general stops at the border. The interviewee of the TBH is convinced of their impact across the border.

“Well, I think we created impact. I just assume so. Of course, this is also a long process. It doesn't come overnight. And it has to get stuck in the minds of the people in the region first." (TBH)

\section{Discussion}

Based upon the empirical results, we notice revealing differences between both expert groups and between the governance levels within the expert groups. This accounts for both the drivers and the characteristics.

With regards to the drivers, our assumption gains significantly more approval from Expert Group 1 compared to Expert Group 2. The EC is fostering a higher participation of small- and medium-sized enterprises (SMEs) in territorial programs already for a longer period $[6,18]$. The deviation on the drivers between Expert Group 1 and Expert Group 2 as shown in Table 2 may be a reflection of this persistent lack of participation of SMEs in territorial programs $[6,10]$. The interviewees from Expert Group 1 on EU, national, and regional level are more closely involved in EU policy processes because of their role as a politician, policymaker, or policy advisor. During the interviews they explain their efforts to stimulate entrepreneurial activities in cross-border cooperation. The empirical results from Expert Group 2, however, express less awareness of the EC fostering involvement of social entrepreneurship in cross-border cooperation programs and projects.

On the local level, however, Table 2 shows much more aligned empirical results for the drivers between Expert Group 1 and Expert Group 2 which indicates that policies play a more limited role. The interviewees are involved in the daily practice of doing businesses across the border. Indeed, the AMB has a very positive view which is in line with the results on EU, national, and regional level. But the empirical results in Table 2 also demonstrate how the AMB mentions attributes coming from Expert Group 2, e.g., social needs, mission driven, social problems, and combining resources. The other way around, the interviewees from Expert Group 2 on local level, envision strong opportunities which include attributes from Expert Group 1, e.g., economic asymmetries, economic cooperation, neighborly communication, social cooperation, and small scale business cooperation [58].

With regards to the characteristics of local embeddedness and social capital, the empirical results as shown in respectively Tables 3 and 4 demonstrate more coherence between Expert Group 1 and Expert Group 2 as compared to the drivers. But sometimes we notice a difference in interpretation of characteristics which sometimes leads to different opinions. For instance, local embeddedness is not always explained in the same manner. On EU level, Expert Group 1 explains local embeddedness 
as being embedded in regional democratic processes. And indeed, this is an important element for stakeholder processes to establish regional policy priorities for Interreg programs. Expert Group 2 considers local embeddedness as being connected with local communities, businesses, and institutions. We find a similar pattern in the empirical results for social capital. On EU and national levels trust is sometimes explained as the trust between countries on a higher level of aggregation, e.g., trust between politicians or organizations [59]. However, on regional and local levels trust is also something that happens very locally between people that actually reside and work in the border region.

To mitigate the disturbing impact of a lack of trust in cross-border cooperation processes, the institutional approach may prevail as an option for cooperation. The reason for this being to limit the human factor, which lies often at the bottom of the lack of trust (AEBR). This is in line with the findings of Koch (2018) [37], which show better trust-building through top-down organized cross-border cooperation. Because social capital is an important resource for social enterprises, trust building may come with extra transaction costs by entering the cross-border market. On the other hand, people on the ground are seen as the experts of cross-border cooperation (MOT). Positioning social entrepreneurship between the institutional approach and people as the experts on the ground may contribute to trust building. Another view on trust is posted by social entrepreneur YUM who argues that trust plays an important role for consumers buying from social enterprises. Trust in the sustainability of the product and the underlying organization is essential to establish a social business in a new market.

With regards to the characteristic of commercial activities, Table 5 shows a gap between the EU levels and the national/regional level of Expert Group 1 in their response to the relation between commercial activities and economic/social development. In general, institutional EU cross-border cooperation is not envisioned as a commercial activity by nature. However, the interviewees on EU level express how commercial activities can be applied to foster cross-border cooperation $[11,58]$. For instance, the MEP fosters a stronger link between the EU territorial programs and EU innovation programs, such as H2020. And therefore, SMEs are needed to participate in EU territorial programs. This should lead to more social innovation and regional development. On national, regional, and local level commercial activities are less related to cross-border cooperation. The experts think that the current social enterprise sector on regional and local level is too small to reach a critical mass for creating substantial impact. Table 5 demonstrates how all governance levels of Expert Group 2 relate commercial activities to economic and social development. These experts have a shared vision on how social enterprises can create positive impact on a small scale for specific target groups and as such, realize economic and social goals.

The empirical results show the potential effects of social entrepreneurship on economic and social development in EU border regions. Examples of these are matching supply and demand on the labor market (TBH), mitigating negative effects of the crisis (MOT) and bringing together people with a similar historical backgrounds (MOT). To create a sustainable impact, commercial activities are needed for continuity of the social business. Social enterprises often face difficulties in scaling up their businesses due to lacking financial resources. Reaching out across the border, however, could be a possible strategy for scaling-up (MOT) eventually with the business support coming from Euregions. Other strategies to cross the border may be social franchising which is a relative new concept applied by social enterprises located in different European cities (EUCL, HFB). Or the implementation of a successful social business model in the neighboring country (YUM). SEUK observes a growing number of local community ownership to solve local problems.

\section{Conclusions}

The aim of our current research is to find an answer to the question if complementarity exists between social entrepreneurship and institutional EU cross-border cooperation. The rationale behind the research question is that both concepts endeavor similar objectives, but that an untapped potential may exist in the complementarity between the two concepts which could result in sustainable cross-border cooperation. 
Assumption 1 could not be fully confirmed, because Expert Group 2 on EU and national level seems to be more reluctant to institutional EU cross-border cooperation. The opportunity to enter markets across the border is not always envisioned as an opportunity. On these levels a better exchange of knowledge and practices is necessary between EC policymakers and social enterprise interest organizations. An option could be that the EC creates specific room for social enterprises in the Common Provision Regulation (HoR). Moreover, the often local focus and risk avoiding strategies of social entrepreneurs may be reasons not to extend its social business across the border.

We could find confirmation of assumption 1 on the local governance level. Social entrepreneurs are positive about their cooperation with the Euregions. This resulted in benefits for social inclusion on the labor market, local economic and social development, and solving environmental problems. To lower transaction costs or to finance market entry, social enterprises could make use of institutional EU cross-border cooperation and Interreg projects. And the other way around, institutional EU cross-border cooperation could benefit from assets of social enterprises, such as an entrepreneurial drive, local embeddedness, and the building of trust. On local level the empirical results show complementarity between institutional EU cross-border cooperation and social entrepreneurship, which is brought into practice in different regions.

Assumptions 2 and 3 are confirmed and reflect the importance of local embeddedness and social capital in the context of local/regional daily life problems. Concerning local embeddedness, the outcomes of Expert Group 1 could be seen in line with the wish of the EC to have a Europe closer to the citizens in the forthcoming program period 2021-2027. This is would be an opportunity for social entrepreneurship to (1) play a bridging role in institutional EU cross-border cooperation, and (2) to complement the institutional EU cross-border cooperation processes and to perpetuate project results. Concerning social capital, trust is seen as a necessity for sustainable cooperation. Interviewees think that the participation of social enterprises in institutional EU cross-border cooperation could contribute to trust building processes, because of the more bottom-up approach.

Assumption 4 is confirmed by the empirical results. Although commercial activities are not an aspect of institutional EU cross-border cooperation by nature, commercial activities coming from social enterprises are seen as an effective means to complement institutional EU cross-border cooperation and to create regional impact. Moreover, being self-sustainable with profits that flow back to increase the impact is seen as a strong proposition. Two critical remarks, however, go along with this: (1) The difficult position of social enterprises compared to commercial enterprises and (2) the relative small size of the social industry in most European countries and border regions.

Summarizing, we conclude that based upon their drivers and characteristics social entrepreneurship and institutional EU cross-border may complement each other, leading to a sustainable form of cross-border cooperation. Mutual drivers and characteristics offer opportunities to have a Europe closer to the citizens. The complementarity between the concepts is mainly in carrying out the opportunity to an effect. Although the social entrepreneur does not endeavor cross-border cooperation by nature, it might be an attractive opportunity to enter new markets, thereby strengthening social cohesion.

Our research provides primarily an answer to our research question, but many new questions have been raised and remain unanswered. One of them being 'the why' of the absence of social entrepreneurs in cross-border cooperation and/or the current institutional EU cross-border programs and projects $[6,27,36]$. The EC, policymakers, and Euregions foster the participation of social entrepreneurs, but we observe a gap between how opportunities are envisioned by both expert groups. A potential direction for further research in this context may be in cluster cooperation development as described by [27]. We recommend an in-depth case study to investigate how social enterprises could be included in regional clusters established in border regions to strengthen sustainable cross-border entrepreneurship. A second direction for further research is in the strategy chosen to enter the neighboring cross-border market, and to overcome entrepreneurial barriers, e.g., transaction costs, a lack of trust, or language problems. Interviewees provided different options such as social franchising, 
copy-pasting a successful social business model, and local community ownership. Regardless of which option, entering a cross-border market will confront the social entrepreneur with barriers. And also, in the context of regulations, e.g., product requirements, and legal constraints further research is needed. An interesting lead may be the European Grouping of Territorial Cooperation (EGTC) instrument as mentioned by the interviewee of the MEP. The EGTC was developed by the EC to enable regional and local authorities and other public bodies from different EU Member States, to set up cooperation groupings with a legal personality, and as such promote cross-border cooperation. The instrument was implemented in 2016 and a first impact analysis could deliver interesting new insights, also in the context of social enterprises' ecosystems.

Author Contributions: Conceptualization: H.T.W. and C.L.V.; methodology: H.T.W.; software, H.T.W.; validation: H.T.W., C.L.V.; formal analysis: H.T.W.; investigation: H.T.W.; resources, H.T.W., C.L.V., and F.d.L.; data curation: H.T.W. and F.d.L.; writing-original draft preparation, H.T.W. and C.L.V.; writing一review and editing H.T.W. and C.L.V.; visualization: H.T.W. and C.L.V; supervision: C.L.V. and F.d.L.; project administration: H.T.W. and C.L.V. All authors have read and agreed to the published version of the manuscript.

Funding: This research received no external funding.

Conflicts of Interest: The authors declare no conflict of interest.

\section{References}

1. European Commission. A Map of Social Enterprises and Their Eco-Systems in Europe; Publications Office of the European Union: Brussels, Belgium, 2015.

2. Orhei, L.; Vinke, J.; Nandram, S.S. Are social enterprises in Romania EMES social enterprises? Rev. Manag. Comp. Int. 2014, 15, 154.

3. Wronka-Pośpiech, M. The identification of skills and competencies for effective management in social enterprises. A managerial perspective. Management 2016, 20, 40-57. [CrossRef]

4. De Beer, M. Local social value creation by neighborhood-based entrepreneurs. Soc. Enterp. J. 2018, 14, 450-469. [CrossRef]

5. Yunus, M.; Moingeon, B.; Lehmann-Ortega, L. Building social business models: Lessons from the Grameen experience. Long Range Plan. 2010, 43, 308-325. [CrossRef]

6. Jakola, F.; Prokkola, E.K. Trust Building or Vested Interest? Social Capital Processes of Cross-Border Co-Operation in the Border Towns of Tornio and Haparanda. Tijdschr. Voor Econ. Soc. Geogr. 2018, 109, 224-238. [CrossRef]

7. Perkmann, M. Cross-border regions in Europe: Significance and drivers of regional cross-border co-operation. Eur. Urban Reg. Stud. 2003, 10, 153-171. [CrossRef]

8. Lepik, K.-L. Euroregions as mechanisms for strengthening cross-border cooperation in the Baltic Sea region. Trames 2009, 13, 265-284. [CrossRef]

9. Greta, M. Euroregion in the Role of Management of Structural Aid and as a Natural Cluster. Organ. Manag. Q. 2016, z63, 33-43.

10. Sousa, L.D. Understanding European cross-border cooperation: A framework for analysis. J. Eur. Integr. 2013, 35, 669-687. [CrossRef]

11. Portolés, J.B. Cross-Border Cooperation and Cultural Communities in Europe; Centre Maurits Coppieters: Brussels, Belgium, 2015.

12. Christodoulou, A.; Christidis, P. Bridges across borders: A clustering approach to support EU regional policy. J. Transp. Geogr. 2020, 83, 102666. [CrossRef]

13. Kurowska-Pysz, J.; Szczepańska-Woszczyna, K. The analysis of the determinants of sustainable cross-border cooperation and recommendations on its harmonization. Sustainability 2017, 9, 2226. [CrossRef]

14. Böhm, H.; Opioła, W. Czech-Polish Cross-Border (Non) Cooperation in the Field of the Labor Market: Why Does It Seem to Be Un-De-Bordered? Sustainability 2019, 11, 2855. [CrossRef]

15. Krätke, S. Regional integration or fragmentation? The German-Polish border region in a new Europe. Reg. Stud. 1999, 33, 631-641. [CrossRef]

16. Paasi, A.; Prokkola, E.-K. Territorial dynamics, cross-border work and everyday life in the Finnish-Swedish border area. Space Polity 2008, 12, 13-29. [CrossRef] 
17. Yndigegn, C. Reviving unfamiliarity-The case of public resistance to the establishment of the Danish-German Euroregion. Eur. Plan. Stud. 2013, 21, 58-74. [CrossRef]

18. European Commission. Communication from the Commission to the Council and the European Parliament: Boosting Growth and Cohesion in Border Regions. Available online: https:/www.ita-slo.eu/sites/default/ files/COM0534_EN_Boosting.pdf (accessed on 14 October 2020).

19. Belz, F.M.; Binder, J.K. Sustainable entrepreneurship: A convergent process model. Bus. Strategy Environ. 2017, 26, 1-17. [CrossRef]

20. Vial, V. A business model canvas for social enterprises. Sains Hum. 2016, 8, 1-2. [CrossRef]

21. Gawell, M.; Pierre, A.; von Friedrichs, Y. Societal Entrepreneurship-A cross-boundary force for regional and local development cherished for multiple reasons. Scand. J. Public Adm. 2014, 18, 109-130.

22. Jorgenson, D.W.; Goettle, R.; Ho, M.S.; Slesnick, D.T.; Wilcoxen, P.J. The distributional impact of climate policy. BE J. Econ. Anal. Policy 2011, 10, 1-28. [CrossRef]

23. Leick, B. Barriers to co-operation and competitive advantage: Cross-border business networks of Saxon and Northern Bohemian firms. J. East Eur. Manag. Stud. 2011, 16, 162-184. [CrossRef]

24. Smallbone, D.; Welter, F. Cross-border entrepreneurship. Entrep. Reg. Dev. 2012, 24, 95-104. [CrossRef]

25. Chobal, L.; Lalakulych, M. Problems and Prospects of Cooperation of The Border Regions of Ukraine, Romania, Moldova And Slovakia. Balt. J. Econ. Stud. 2019, 5, 189-196. [CrossRef]

26. Jelinčić, D.A.; Tišma, S.; Lantos, Z.; Tolić, I. Cross the Border: Participative Integrated Approach to Sustainable Tourism Planning. Geosciences 2019, 9, 434. [CrossRef]

27. Kurowska-Pysz, J. Opportunities for cross-border entrepreneurship development in a cluster model exemplified by the Polish-Czech border region. Sustainability 2016, 8, 230. [CrossRef]

28. Stverkova, H.; Pohludka, M.; Kurowska-Pysz, J.; Szczepańska-Woszczyna, K. Cross-border enterpreneurship in Euroregion Beskydy. Pol. J. Manag. Stud. 2018, 18.

29. Interreg Europe. Available online: https://www.interregeurope.eu/fileadmin/user_upload/documents/Call_ related_documents/Interreg_Europe__Programme_manual.pdf (accessed on 14 October 2020).

30. Mair, J.; Marti, I. Social entrepreneurship research: A source of explanation, prediction, and delight. J. World Bus. 2006, 41, 36-44. [CrossRef]

31. Plotnieks, D. Mechanisms fostering Social Entrepreneurship as potential instruments for Economic development: The Eastern partnership perspective. Balt. J. Eur. Stud. 2014, 4, 34-49. [CrossRef]

32. Mair, J.; Battilana, J.; Cardenas, J. Organizing for society: A typology of social entrepreneuring models. J. Bus. Ethics 2012, 111, 353-373. [CrossRef]

33. Han, M.; McKelvey, B. How to grow successful social entrepreneurship firms? Key ideas from complexity theory. J. Enterprising Cult. 2016, 24, 243-280. [CrossRef]

34. Smith, B.R.; Stevens, C.E. Different types of social entrepreneurship: The role of geography and embeddedness on the measurement and scaling of social value. Entrep. Reg. Dev. 2010, 22, 575-598. [CrossRef]

35. Paasi, A.; Prokkola, E.K.; Saarinen, J.; Zimmerbauer, K. (Eds.) Borderless Worlds for Whom? Ethics, Moralities and Mobilities; Routledge: London, UK, 2018.

36. Prokkola, E.-K.; Zimmerbauer, K.; Jakola, F. Performance of regional identity in the implementation of European cross-border initiatives. Eur. Urban Reg. Stud. 2015, 22, 104-117. [CrossRef]

37. Koch, K. The spatiality of trust in EU external cross-border cooperation. Eur. Plan. Stud. 2018, 26, 591-610. [CrossRef]

38. Promoting People-to-People Contacts through Cross-Border Cooperation Programs in Eastern Partnership Countries. Available online: https://cor.europa.eu/en/our-work/Documents/CORLEAP/Pavel_Branda_ People_to_People_Contacts_final_EN.pdf (accessed on 14 October 2020).

39. Birrell, D.; Hayes, A. Managing cross-border cooperation between voluntary organizations in Ireland. Nonprofit Manag. Leadersh. 2004, 15, 41-53. [CrossRef]

40. Emelyanov, V.; Chechurina, M.; Fischer, P.; Jørgensen, E.J.B. Cross border ventures and their border-crossing strategies. The Case of Russian and Norwegian "Born Borders". Organ. Vadyb. Sist. Tyrim. 2011, 60, 79-92.

41. Policy Brief on Scaling the Impact of Social Enterprises. Available online: https://www.oecd.org/cfe/leed/ Policy-brief-Scaling-up-social-enterprises-EN.pdf (accessed on 14 October 2020).

42. Jenner, P. Social enterprise sustainability revisited: An international perspective. Soc. Enterp. J. 2016, 12, 1-29. [CrossRef] 
43. Doherty, B.; Haugh, H.; Lyon, F. Social enterprises as hybrid organizations: A review and research agenda. Int. J. Manag. Rev. 2014, 16, 417-436. [CrossRef]

44. Association of European Border Regions (AEBR) and European Commission. Practical Guide to Cross-Border Cooperation, 3rd ed.; ABER and EC: Gronau, Germany, 2000.

45. Medeiros, E. Should EU Cross-Border Cooperation Programmes Focus Mainly on Reducing Border Obstacles? Universidad Autónoma de Barcelona: Bellaterra, Spain, 2018; Volume 3, pp. 467-491.

46. Mswaka, W. Conceptualisation of social enterprise in the UK: A contemporary perspective. Iberoam. J. Strateg. Manag. (IJSM) 2015, 14, 6-14. [CrossRef]

47. Folmer, E.; Nederveen, C.; Schutjens, V. Network importance and use: Commercial versus social enterprises. Soc. Enterp. J. 2018, 14, 1-22. [CrossRef]

48. Spear, R.; Bidet, E. Social enterprise for work integration in 12 European countries: A descriptive analysis. Ann. Public Coop. Econ. 2005, 76, 195-231. [CrossRef]

49. Dobele, L.; Dobele, A. Economic Gains from Social Entrepreneurship Development in Latvia. Reg. Form. Dev. Stud. 2014, 14, 30-39. [CrossRef]

50. Jabłoński, A.; Jabłoński, M. Trust as a Key Factor in Shaping the Social Business Model of Water Supply Companies. Sustainability 2019, 11, 5805. [CrossRef]

51. Wry, T.; York, J.G. An identity-based approach to social enterprise. Acad. Manag. Rev. 2017, 42, 437-460. [CrossRef]

52. Arieli, T.; Cohen, N. Policy entrepreneurs and post-conflict cross-border cooperation: A conceptual framework and the Israeli-Jordanian case. Policy Sci. 2013, 46, 237-256. [CrossRef]

53. Hong, B.; Li, Z.; Minor, D. Corporate Governance and Executive Compensation for Corporate Social Responsibility. J. Bus. Ethics 2016, 136, 199-213. [CrossRef]

54. Ikram, A.; Li, Z.; Minor, D. CSR-Contingent Executive Compensation Contracts. J. Bank. Financ. 2018, 105655. [CrossRef]

55. Roy, M.J.; McHugh, N.; Huckfield, L.; Kay, A.; Donaldson, C. “The most supportive environment in the world"? Tracing the development of an institutional 'ecosystem' for social enterprise. Volunt. Int. J. Volunt. Nonprofit Organ. 2015, 26, 777-800. [CrossRef]

56. Baarda, D.B.; Bakker, E.; Fischer, T.; Julsing, M.; Goede, M.P.M.; Peters, V.A.M.; van der Velden, T.M. Basisboek Kwalitatief Onderzoek: Handleiding Voor Het Opzetten en Uitvoeren van Kwalitatief Onderzoek; Noordhoff Uitgevers: Groningen, The Netherlands, 2013.

57. Taylor, W. Taylor 17 Analysis of qualitative data. In Research Methods in Sports Coaching; Nelson, L., Groom, R., Potrac, P., Eds.; Routledge: London, UK, 2014; pp. 182-191.

58. Voinea, C.L.; Hoogenberg, B.-J.; Fratostiteanu, C.; Bin Azam Hashmi, H. The Relation between Environmental Management Systems and Environmental and Financial Performance in Emerging Economies. Sustainability 2020, 12, 5309. [CrossRef]

59. Rauf, F.; Voinea, C.L.; Bin Azam Hashmi, H.; Fratostiteanu, C. Moderating Effect of Political Embeddedness on the Relationship between Resources Base and Quality of CSR Disclosure in China. Sustainability 2020, 12, 3323. [CrossRef]

Publisher's Note: MDPI stays neutral with regard to jurisdictional claims in published maps and institutional affiliations.

(C) 2020 by the authors. Licensee MDPI, Basel, Switzerland. This article is an open access article distributed under the terms and conditions of the Creative Commons Attribution (CC BY) license (http://creativecommons.org/licenses/by/4.0/). 